\title{
Erratum to: The Financial Efficiency of Biogas Stations in Poland
}

Serhiy Zabolotnyy and Mariia Melnyk

\section{Erratum to:}

Chapter "The Financial Efficiency of Biogas Stations in Poland" in: K. Mudryk and S. Werle (eds.), Renewable Energy Sources: Engineering, Technology, Innovation, Springer Proceedings in Energy, https://doi.org/10.1007/978-3-319-72371-6_9

The original version of the book was inadvertently published with incorrect author name "Melnyk Mariia", which has been now corrected to read as "Mariia Melnyk" in chapter "The Financial Efficiency of Biogas Stations in Poland". The erratum chapter and the book have been updated with the change. 